Ks. Arkadiusz Jasiewicz

WSD, Przemyśl

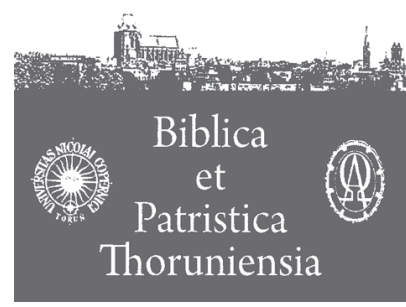

5 (2012) ISSN 1689-5150

\title{
Interpretacja „Komentarza do Apokalipsy” Andrzeja z Cezarei i jego znaczenie dla krytyki tekstu biblijnego
}

\section{The Apocalypse Commentary of Andrew of Caesarea - his interpretation and influence on the critical text of the Revelation}

Słowa klucze: Andrzej z Cezarei, Apokalipsa, krytyka tekstu.

Key words: Anfrew of Caesarea, Apokalypse, critical text.

$\mathrm{K}$ sięgę Apokalipsy od samego początku Kościół starożytny uważał za ważną lekturę. Już jednak w II wieku użytek, jaki z tej księgi uczynili montaniści i millenaryści, wytworzył pewną nieufność, tak że Wschód chrześcijański miał wątpliwości przed włączeniem jej do kanonu Nowego Testamentu ${ }^{1}$. Istotnie, cytaty pochodzące $\mathrm{z}$ tego dzieła są rzadkie u pisarzy IV i V wieku². Zachód natomiast ze swej strony nie miał zasadniczo większych trudności z uznaniem Apokalipsy za księgę natchnioną, w związku z czym pisarze późnej starożytności, od III do VIII wieku, pozostawili po sobie całą serię komentarzy, w których

1 Zob. świadectwa przytoczone przez Euzebiusza z Cezarei, Historia Kościelna III, 24, 18; tł. A. Lisiecki, Poznań 1924, s. 123; 25, 2, s. 124; 28, 2; s. 127; 31, 6, s. 131; VII, 25, 16, s. 340. Na temat przedstawionej przez Euzebiusza opinii co do kanoniczności Apokalipsy por. C. Mazzucco, Alla ricercadelle prime interpretazioni dell'Apocalisse, „Parole di Vita” 25 (1980), s. 446-450; M. Simonetti, Między dosłownościq a alegorią. Przyczynek do historii egzegezy patrystycznej, tł. T. Skibiński, Kraków 2000, 311-312; J. Irmscher, La valutazione dell'Apocalisse di Giovanni nella chiesa antica, „Augustynianum” 29 (1989), s. 171-176.

2 Na temat obecności Apokalipsy św. Jana u Atanazego, Ojców Kapadockich i Cyryla por. A. Monaci Castagno, I Commenti di Ecumenio e di Andrea di Cesarea: due letture divergenti dell'Apocalisse, „Memorie dell'Accademia delle Scienze di Torino”, 5 (1981), s. 388nn. 
wyrażali swoją interpretację Janowego dzieła ${ }^{3}$. Na Wschodzie zaś po prawie dwóch wiekach milczenia na temat Apokalipsy, pomiędzy jej odrzuceniem a nieśmiałym przemilczaniem, dopiero $\mathrm{w}$ VI wieku pojawia się tam komentarz w dwunastu księgach pióra niejakiego Ekumeniusza ${ }^{4}$, autora pierwszego całościowego greckiego komentarza do Apokalipsy ${ }^{5}$. Jego komentarz wskazuje na apostolskie autorstwo Apokalipsy, odrzuca millenaryzm, podaje interpretacje odnoszące proroctwa jednakowo do przeszłości, teraźniejszości i przyszłości, czyli do całej historii zbawienia z Wcieleniem, jako momentem kluczowym. Widać w tym pewną zależność od Orygenesa ${ }^{6}$. Jednak jeszcze większe znaczenie dla krytyki tekstu Apokalipsy odegrał Komentarz do Apokalipsy św. Jana sporządzony przez Andrzeja z Cezarei, żyjącego na przełomie VI i VII wieku. Autor ten zapewne czytał komentarz Ekumeniusza i często odwoływał się do jego opinii, choć nigdy z imienia, po to tylko, by z nim polemizować. Oba te komentarze warte są zatem zauważenia, nie tylko dlatego, że są pierwszymi i najważniejszymi greckimi komentarzami do Apokalipsy, ale także dlatego, iż oba teksty stanowią jeden $\mathrm{z}$ najwcześniejszych sporów na temat znaczenia i interpretacji Apokalipsy dla wiary i życia Kościoła. Z dzieła Andrzeja korzystali późniejsi komentatorzy Apokalipsy, m.in. Aretos z Cezarei (X w.), Erazm z Rotterdamu (XVI w.), a także inni autorzy nowożytni. Komentarz ten przyczynił się także do umocnienia pozycji Apokalipsy na Wschodzie i odrzucenia wątpliwości co do jej przynależności do kanonu Nowego Testamentu.

Podkreślona wyżej wartość i znaczenie Komentarza do Apokalipsy Andrzeja z Cezarei obliguje nas do szerszego omówienia najpierw życia biskupa z Cezarei, jego myśl teologiczną, a następnie jego specyficzną interpretację Apokalipsy św. Jana i sam wpływ komentarza na krytykę tekstu biblijnego.

3 Przegląd łacińskich komentarzy Apokalipsy od III do VIII wieku podaje R. Gryson, Les commentaires patristiques latins de l'Apocalypse, „Revue Théologique de Louvain” 28 (1997), s. 305-307. Wyd. polskie: Pierwsze Łacińskie Komentarze do Apokalipsy Hipolita, Wiktoryna, Hieronima, Tykoniusz, t. 1, red. D. Budzanowska i W. Linke, Warszawa 2011.

4 O trudnościach w identyfikacji tej osoby zob. M. Dulaey, Oecuménius, w: Dictionnaire de spiritualité ascétique et mystique, doctrine et histoire, t. 11, Beauchesne 1994, kol. 681-682; W. Myszor, Ekumeniusz, w: C.V. Manzanares, Pisarze wczesnochrześcijańscy IVII w. Mały słownik, Warszawa 2001, s. 63. Najczęściej w osobie Ekumeniusza rozpoznaje się filozofa i stronnika Sewera z Antiochii albo biskupa z Trikki w Tesalii.

5 M. Dulaey, Oecuménius, DS, t.11, kol. 681. Wydanie krytyczne: H.C. Hoskier, The complete commentary of Oecumenius on the Apocalypse, Unversity of Michigan 1928.

6 H. Pietras, Starożytne spory wokół Apokalipsy, w: Judeochrześcijańskie elementy w literaturze patrystycznej, Studia Antiquitatis Christianae 13, Warszawa 1998, s. 41. 


\section{Czas działalności Andrzeja z Cezarei}

Osoba Andrzeja z Cezarei ${ }^{7}$ okryta jest aurą tajemniczości i milczenia, gdyż o życiu jego nie ma prawie żadnych danych ${ }^{8}$. Pozostawił po sobie Komentarz do Apokalipsy i i kilka fragmentów pytań i odpowiedzi pod nazwą Lecze-

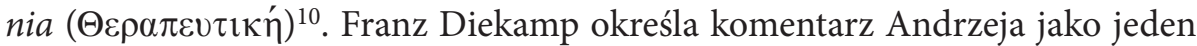
z najstarszych komentarzy do Apokalipsy i datuje go na początek V wieku' ${ }^{11}$. Data ta została skorygowana, gdy odkryto w Messyni manuskrypt komentarza Ekumeniusza, który jasno wykazał, że skoro Andrzej korzystał z Ekumeniusza, to datację jego trzeba przesunąć na późniejszy czas. Można przypuszczać, że Andrzej napisał swój komentarz przed rokiem 637, czyli przed opanowaniem miasta Jerozolimy przez islam ${ }^{12}$. Skłania do takich wniosków sama interpretacja Andrzeja tekstu Ap 16,9, gdzie określa „wielkie miasto” jako Jerozolimę, podzieloną na trzy części: Chrześcijanie, Żydzi i Samarytanie: „W tym czasie Żydzi i Samarytanie, ukrywając swoje prawdziwe intencje z obawy przed naszymi pobożnymi władcami, wydają się we wspólnocie z nami, nie oddzielając się równocześnie od własnego ludu” ${ }^{3}$. Nie ma tutaj wzmianki, że „w tym cza-

7 Podstawowe prace: E.S. Constantinou, Andrew of Caesarea and the apocalypse in the ancient church of the East: Studies and Translation. PhD thesis, Quebec: Université Laval, 2008; Greek Commentaries on Revelation. Oecumenius and Andrew of Caesarea (Ancient Christian Texts), tr. W.C. Weinrich, ed. Thomas C. Oden, InterVarsity Press 2011.

8 Zob. P. Apollinaire, André de Césairée, w: Dictionnaire de la Bible, Supplément t. 1, kol. 564; por. K. Obrycki, Andrzej, w: Encyklopedia Kultury Bizantyńskiej, red. O. Jurewicz, Warszawa 2002, s. 33.

9 CPG 3, 7478; wersja krytyczna dzieła: J. Schmid, Studien Zur Geschichte des grieschischen Apokalypse-Textes, 3 parts. Part 1, Der Apokalypse-Kommentar des Andreas von Kaisareia. Part 2, Die alten Stamme. Part 3, Historische Abteilung Erganzungsband, Einleitung. Mùnchener Theologische Studien: Karl Zink Verlag, 1955-56 (dalej posługuję się skrótem MTS).

10 Fragmenty te zostały opublikowane przez F. Diekamp, Andreas von Caesarea, „Analecta Patristica": Texte und Abhandlungen zur Griechischen Patristik. Orientalia Christiana Analecta, vol. 117. Rome: Pontifical Institute of Oriental Studies, 1938, 161-72. Przypisywany jemu Komentarz do Daniela nie jest potwierdzony w manuskryptach (CPG 7478).

11 Diekamp wierzy, że pewne wydarzenia opisane w komentarzu pochodzą jeszcze z czasów najazdu Hunów, dlatego datuje komentarz na 515 rok. Por. F. Diekamp, Das Zeitalter des Erzbischofs Andreas von Caesarea, „Historisches Jahrbuch” 18 (1897), s. 1-3.27-28.

12 Zob. W. C. Weinrich, Translator's introduction, w: Greek Commentaries on Revelation..., s. XXXIII-IV.

13 MTS 1, 178. 
sie” przebywali też Arabowie, a odniesienie do „naszych pobożnych władców” sugeruje, że chrześcijańscy władcy bizantyjscy pełnili jeszcze swoje funkcje ${ }^{14}$.

Określając terminus post quem komentarza Andrzeja wydaje się mało prawdopodobne, by to było wcześniej niż rok 563. Lista biskupów Cezarei w Kapadocji jest znana z imienia w latach między 510 a 563. Theokritos, biskup Cezarei umiera w 563 roku i po nim w tym samym roku Andrzej staje się arcybiskupem metropolitarnego miasta Kapadocji, drugiego co do ważności po Konstantynopola ${ }^{15}$. Możemy zatem przyjąć z małymi wyjątkami, że Andrzej był arcybiskupem Cezarei na przełomie 2. połowy VI wieku, a 1. połowy VII wieku i w tym czasie napisał swój Komentarz do Apokalipsy.

\section{Teologia biskupa z Cezarei ${ }^{16}$}

W swojej doktrynie teologicznej Andrzej z Cezarei pozostawał wierny wyznaniu nicejskiemu o prawdziwym Bóstwie Syna Bożego, a także przyjmował nauczanie Soboru Chalcedońskiego o dwóch naturach w Chrystusie. W porównaniu do Ekumeniusza odrzuca monofizytyzm. Chrystus jest prawdziwym Bogiem, „kierującym wszystkim, nie mający ograniczeń i przebywający w wieczności razem z Ojcem"17. Jako Król królów i Pan panów Chrystus jest władcą wszelkiego królestwa, „równy w mocy z Ojcem i zjednoczony istotowo z Nim”" ${ }^{18}$. Słowa z Apokalipsy: „który jest, który był i który przychodzi” odnoszą się - zdaniem Andrzeja - do „potrójnej hipostazy Bóstwa” ( $\tau \bar{\eta} \varsigma \tau \rho ı \sigma i \pi o \sigma \tau$

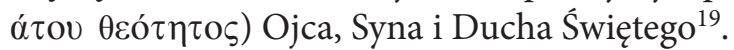

14 Zob. E.S. Constantinou, Andrew of Caesarea and the apocalypse..., s. 2-3. Castagno uważa, że Andrzej czyni tutaj aluzję do wyników różnych praw państwowych skierowanych przeciw Żydom i Samarytanom, kiedy to wielu z nich przyjęło chrzest i stało się chrześcijanami, chociaż w sercu pozostając wierny swojej pierwotnej wierze. Por. A. Monaci Castagno, Il Problema della datazione dei commenti al' Apocalisse di Ecumenio e di Andrea di Cesarea, „Atti della Accademia delle scienze di Torino II, Classe de scienze, morali, storiche e filologiche" 114 (1980), s. 240-41.

15 F. Diekamp, Andreas von Caesarea, 162. Według Diekampa biskupami są: Soterichus (510-537), Theodorus Askidas (537-558), Theokritus (558-563). Znamy imiona arcybiskupów Cezarei do 563 r., to jednak przypuszcza się, że Andrzej był arcybiskupem w latach 563-614.

16 Zob. E.S. Constantinou, Andrew of Caesarea and the apocalypse..., s. 195-233.

17 MTS 1,17-18 do słów Ap 1,8: „Ja jestem Alfa i Omega, mówi Pan, Który jest, Który był i Który przychodzi, Wszechmogący".

18 MTS 1,14 do Ap 1,5. Andrzej używa terminu nicejskiego ónoov́øıs.

19 MTS 1,13 do Ap 1,4. 
Inne wypowiedzi chrystologiczne u Andrzeja są także zgodne z ortodoksją i pozbawione polemicznych odniesień. Przykładem może być interpretacja stóp $z$ drogocennego metalu u Syna Człowieczego (Ap 1,15) jako obraz dwóch natur w Chrystusie: „Podczas gdy drogocenny metal symbolizuje naturę ludzką, a kadzidło naturę boską, to słodki zapach wiary wskazuje na niezmieszaną jedność" 20 , i dodaje jeszcze, iż stopy te symbolizują „niepodzielną i niezmieszaną jedność bóstwa i człowieczeństwa"21. Trzeba jednak przyznać, że sam biskup z Cezarei stronił od wszelkich debat chrystologicznych prowadzonych szczególnie po Soborze Chalcedońskim ${ }^{22}$.

Zauważyć jednak można u Andrzeja z Cezarei zainteresowanie tematami, dotyczącymi eschatologii, poruszanymi w VI wieku ${ }^{23}$. Na to wskazuje jego odmienna od Ekumeniusza koncepcja proroctwa Apokalipsy. Jak wielokrotnie stwierdza ma ona za przedmiot nie przeszłość, ale teraźniejszość i przyszłość. Innymi słowy, podstawową tendencją jego komentarza jest ukierunkowanie na eschatologię, jak sam zaznacza w prologu, że został poproszony o zastosowanie proroctwa Jana do czasów przyszłych ${ }^{24}$.

W komentarzu do Ap 16,10-11 Andrzej podnosi kwestię wiecznych cierpień: „Dobroć Boga i Jego wszechwiedza oraz moc wstrzymają wymierzenie kary wiecznej" ${ }^{25}$, chociaż natychmiast dodaje, że ci, którzy uważają się za sprawiedliwych, zawsze „dzielą los, na jaki sobie zasłużyli”. Andrzej zapewne ma na myśli tych, co grzeszą świadomie w poczuciu wolnej woli i z własnego wyboru. Choć Bóg jest gotów okazać miłosierdzie i dobroć, to jednak wyrok cierpień wiecznych jest sprawiedliwy, „ponieważ grzesznicy sami wybrali zło”26. Ten argument skierowany jest bezpośrednio w doktrynę restytucji, która głosi, że wszyscy zostaną oczyszczeni przez Słowo i w Nim będą uczestniczyć. Andrzej

20 MTS 1,21 do Ap 1,15: „Stopy jego podobne do drogocennego metalu, jak gdyby

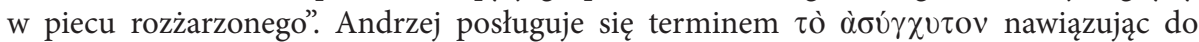
Chalcedonu o dwóch połączonych, ale „niezmieszanych” naturach w Chrystusie.

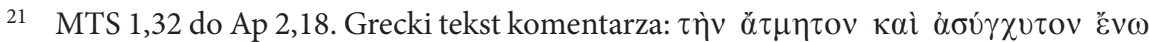

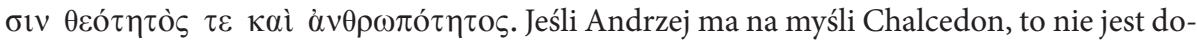
kładny w użyciu terminów. Dla określenia nierozdzielności dwóch natur Chalcedon używa

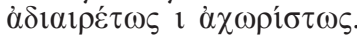

22 Zob. W. C. Weinrich, Translator's introduction, w: Greek Commentaries on Revelation..., s. XXXIV-V.

23 Zob. E. S. Constantinou, Andrew of Caesarea and the apocalypse..., s. 206-217.

24 Począwszy od początku VI w. ożywia na Wschodzie oczekiwanie końca świata i właśnie ta okoliczność tłumaczy ożywienie zainteresowania Apokalipsą; na ten temat por. A. Monaci Castagno, I Commenti..., s. 306.

25 MTS 1,172.

26 MTS 1,179-182. 
nie podziela tutaj opinii Ekumeniusza, że po pewnym czasie cierpienia wieczne staną się bezużyteczne ${ }^{27}$.

Biskup z Kapadocji wierny jest tradycji, która podkreśla ciągłość między pierwszym stworzeniem i wypełnieniem się świata. W komentarzu do Ap 20, 11 i 21,1, konsekwentnie odrzuca sugestię, że materialny świat będzie unicestwiony i na poparcia tej tezy przywołuje na świadków Ireneusza i Metodego. Andrzej uważa, że raczej nastąpi przemiana stworzenia tak, by mogło „uczestniczyć w wolności i chwale dzieci Bożych" (Rz 8,21), stało się jeszcze bardziej doskonałe: „Stworzenie, uczynione dla naszego szczęście stanie się jeszcze doskonalsze, a nie ulegnie unicestwieniu, ponieważ po śmierci nie przestanie istnieć" 28 .

Stosując takie rozumowanie Andrzej zdecydowanie odrzuca dwa poglądy orygenizmu: pierwszy, że materialny świat będzie unicestwiony i drugi, iż tylko duchowe byty pozostaną ${ }^{29}$, dusze zaś rozumne powrócą do pierwotnego stanu jeszcze sprzed upadku ${ }^{30}$. Biskup z Cezarei broni tezy, iż nie śmierć jest końcowym przeznaczeniem duszy, lecz raczej dostosowanie się do życia, w którym przyjdzie jej żyć po śmierci. W komentarzu do Ap 6,11, zaznacza, że męczennicy, których św. Jan „widział w duchu” pod ołtarzem symbolizują nadzieję

27 MTS 1,96-97.

28 MTS 1,227-29.232-33.

29 Zob. XI anatematyzm Przeciw Orygenesowi na Soborze Konstantynopolitańskim II: „Jeśli ktoś uważa, że przyszły sąd będzie polegał na unicestwieniu ciała i kres życia będzie miał wymiar nadnaturalny i że potem już nic nie będzie istnieć, ale tylko istoty rozumne (voūs), niech będzie przeklęty" (Early Church Fathers: Nicene And Post-Nicene Fathers Series 2, 14 Vols. ed. P. Schaff, London 1994, s. 319; dalej używam skrótu NPNF). Sam Orygenes uważa, że materialny świat jest darem dla człowieka, by nie oddalał się w nieskończoność i by mógł wrócić do świata, w którym został stworzony. W przeciwieństwie do gnostyków, Orygenes podkreśla stale, że każdy ma taką możliwość, a jeśli z jakichś powodów nie potrafi lub nie zechce wrócić do Boga w tym życiu, być może otrzyma nową szansę w jakimś przyszłym świecie. Wszystko to jest powiedziane hipotetycznie, gdyż Orygenes wszystko na temat Boga i Jego tajemnic mówił i pisał hipotetycznie. Bardzo rzadko zdarza mu się coś z naciskiem twierdzić, za to bardzo często używa słowa "może” i posługuje się trybem przypuszczającym. Gdy w V wieku o tej jego pokorze naukowej zapomniano i zaczęto przedstawiać jego hipotezy jako twierdzenia, skazano jego pisma na spalenie i potępiono je wraz z ich autorem na Soborze Konstantynopolitańskim II w 553 roku. Zob. Sobór Konstantynopolitański II, anatematyzm XI, Dokumenty Soborów Powszechnych I, Kraków 2001, 294

30 Zob. XV anatematyzm: „Jeśli ktoś sądzi, że życie istot rozumnych wróci do pierwotnego stanu jeszcze sprzed upadku, a kres będzie taki sam jak początek oraz koniec będzie miarą początku, niech będzie przeklęty" (NPNF 2, vol. 14, 319). 
i „prawdziwą radość końcowego spoczynku na łonie Abrahama”" ${ }^{31}$. Ten pogląd jest jeszcze bardziej ukazany przez biskupa w Therapeutike. Na pytanie „gdzie znajdują się dusze po opuszczeniu ciała", Andrzej odpowiada, że przebywają

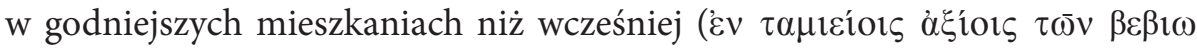

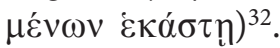

\section{Interpretacja Apokalipsy - metoda, struktura i treść 33}

W prologu do Komentarza do Apokalipsy Andrzej przedstawia swój sposób odczytywania Pisma Świętego i metodę jego interpretacji ${ }^{34}$. Dzieło Janowe objaśnia na trzech poziomach, zestawiając je z trzema częściami natury ludzkiej (ciało/ dusza/duch= litera/tropologia/anagoge). Ciało Pisma czyli litera i treść prowa-

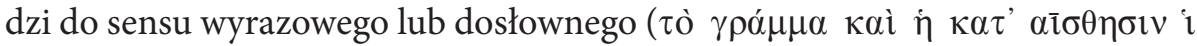

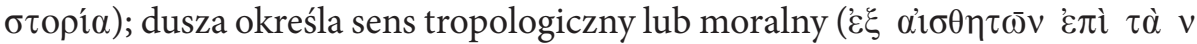

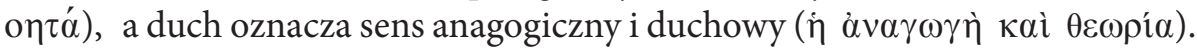
Sens duchowy zdaniem Andrzeja przeważa w Apokalipsie Janowej ${ }^{35}$.

Pomimo potrójnego odczytywania Pisma Świętego, Andrzej nie jest zwolennikiem interpretacji Orygenesa. Odmiennie niż orygeniści, którzy w kwestii sensów poruszali się w sferze idei, Andrzej pozostaje na poziomie struktury biblijnej myśli. Duchowe znaczenie tekstu nie prowadzi duszy na wyższe rzeczywistości, ale raczej ukazuje „Tego, który przychodzi i prowadzi do wyższych rzeczy”. Te „wyższe rzeczy” u Andrzeja nie nawiązują do sfery chrześcijańskiego platonizmu, ale do rzeczywistości Królestwa Bożego, które w przyszłości zostanie dane człowiekowi na wieczność. Potrójna interpretacja tekstu jest uzależniona od duchowych możliwości każdego człowieka ${ }^{36}$. Rzeczy te u Jana Teologa, w pełni poddane są Duchowi i stają się szczególnie odpowiednie do wizji przyszłej szczęśliwości, kiedy wszyscy odkupieni będą „błogosławionymi we wszystkim".

$31 \quad$ MTS 1,67.

32 F. Diekamp, Andreas von Caesarea, 165-66.

33 Por. W. C. Weinrich, Translator's introduction, w: Greek Commentaries on Revelation..., s. XXXVII-IX.

34 MTS 1,8-10.

35 MTS $1,8$.

36 Literalny sens dotyczy „tych, co znają Prawo”, tropologiczny zaś dotyczy „tych, co żyją w łasce”, duchowy zaś „tych, którzy są błogosławieni we wszystkim i w których prawo duchowe zwycięża prawo cielesne i całkowicie są poddani jemu" (MTS 1,8-9). 
Podstawowa perspektywa Apokalipsy w komentarzu jest szczególnie widoczna $w$ trzech kontekstach, rozpatrywanych $\mathrm{w}$ polemice do interpretacji Ekumeniusza. Najpierw koncentruje się na wyjaśnieniu znaczenia symboliki siedmiu pieczęci (Ap 5,1-5). Według Ekumeniusza siedem pieczęci symbolizuje wydarzenia z życia Chrystusa, Andrzej zaś odrzuca taką interpretację i przyjmuje wyjaśnienie Metodego z Olimpu: „iż owym narodzonym jest Chrystus; wszak dawno przed Apokalipsą dopełniła się tajemnica wcielenia Słowa, a Jan głosi wyrocznie o teraźniejszych i przyszłych sprawach" ${ }^{37}$. Interpretuje zatem siedem pieczęci jako wydarzenia, poprzedzające głoszenie przez Apostołów „rozpadu miasta ziemskiego” (Ap 8,1-13). Podobnie cztery żyjące istoty i cztery konie (Ap 6,2-8) przedstawiają teraźniejszą i przyszłą rzeczywistośćc ${ }^{38}$.

Drugi kontekst dotyczy wizji niewiasty, smoka i dziecka (Ap 12,1-18). Przystępując do tłumaczenia rozdziału 12 Apokalipsy, zaznacza on we wstępie, że niektórzy Ojcowie i pisarze kościelni przed Metodym upatrywali w niewieście apokaliptycznej Matkę Słowa Wcielonego; osobiście przeciwstawia się Andrzej tego rodzaju zapatrywaniu, posługując się egzegezą Metodego z Olimpu: „Wielki Metody rozumie niewiastę jako święty Kościół, który w centrum ma Boskie Dziecię, Pana narodzonego przed czasem"39. Pogląd zatem, upatrujący w tej niewieście Słowa Wcielonego oparty był na niedokładnej znajomości dziewiczego porodu Chrystusa, a samo narodzenie Jezusa należy już do przeszłości, tymczasem zdarzenia opisane w Apokalipsie dotyczą przyszłości ${ }^{40}$.

Niewiasta apokaliptyczna zatem jest symbolem Kościoła przyodzianego

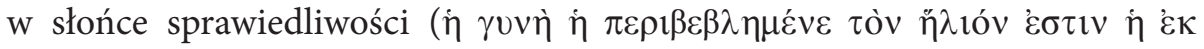
$\left.\kappa \lambda \eta \sigma^{\prime} \alpha\right)^{41}$, a bóle porodowe są wyrazem trudów ponoszonych przez Kościół celem duchowego odrodzenia ludzkości. To duchowe odrodzenie odbywa się na drodze chrztu św., dopóki w człowieku nie będzie ukształtowany Chrystus (por. Gal 4,19). Narodzenie syna, mężczyzny, jest symbolem narodzin członków Chrystusa, których Kościół rodzi na chrzcie św. ${ }^{42}$; pustkowie, na które

37 Metody z Olimpu Uczta VIII, 7, w: Św. Metody z Olimpu, Uczta. Orygenes, Homilie o Pieśni nad Pieśniami i Zachęta do męczeństwa, tł. S. Kalinkowski, PSP 24, Warszawa 1980, s. 76.

38 Biały koń symbolizuje głoszących apostołów, czerwony koń cierpiących męczenników, zaś czarny koń smutek i tych, co upadli w wierze, a blady koń śmierć i zniszczenie.

39 MTS 1,121.

40 Zob. L. Stefaniak, Interpretacja 12 rozdziału Apokalipsy św. Jana w świetle historii egzegezy, Poznań 1957, s. 48.

41 MTS 1,121.

42 Metody z Olimpu, Uczta VIII, 7, PSP 24, s. 77. 
ucieka niewiasta, oznacza mądrość i rodzące się życie ${ }^{43}$. I kończy całą myśl tymi słowami: „Bądź pewny, że to dziać się będzie szczególnie wtedy, gdy nadejdzie antychryst" 4 . Przyszłość zatem jest zawsze punktem odniesienia dla biskupa z Cezarei.

Warto zaznaczyć jeszcze jego interpretację co do tysiąca lat w rozdziale 20 Apokalipsy. Ekumeniusz rozumiał przez tysiąc lat, czas wcielenia Słowa i objawienie się Bóstwa Jezusa oraz związanie diabła na ten czas. Andrzej precyzuje, iż diabeł został związany na Krzyżu Chrystusa i to związanie jest teraźniejszą i przyszłą rzeczywistością. Konsekwencje tego czynu Andrzej widzi w „zniknięciu bałwochwalstwa, zniszczeniu pogańskich świątyń, porzuceniu sprofanowanych ołtarzy i odczytywaniu woli Bożej przez świat”. Liczba tysiąc zatem symbolizuje zarówno „ilość”, jak i „pełnię”, stąd odnosi ją Andrzej do czasu ewangelizacji Kościoła, jak również do okresu od wcielenia do przyjścia Antychrysta, kiedy ludzie zostaną uwolnieni od życia według prawa i staną się „doskonałymi ludźmi” i dojrzeją do pełni Chrystusa (por. Ef 4,13) ${ }^{45}$.

Dlaczego biskup z Cezarei w swojej interpretacji Apokalipsy stosuje przede wszystkim terminy dotyczące teraźniejszości i przyszłości? Odpowiedź leży w jego rozumieniu celu, dla którego objawienia zostały dane Janowi. Bóg pragnie dla całej ludzkości zbawienia i zsyła po to wiedzę prawdy. $\mathrm{Z}$ tego powodu Bóg objawił Janowi rzeczy, które są i które staną się, aby zachęcić i przekonać wszystkich ludzi do pokuty i nawrócenia. Andrzej mocno zaznacza na początku swojego komentarza, że in persona Johannis zostały dane objawienia „głoszące moc i nawrócenie dla tych, którzy usłyszą te rzeczy ukryte przed ludzkością, a które nadejdą w przyszłości”" ${ }^{\prime \prime}$. Biskup z Kapadocji dochodzi to tego samego stwierdzenia przy końcu komentarza. W wołaniu bowiem „Przyjdź, Panie Jezu” widać, że „cała księga jest święta i inspirowana przez Boga, aby prowadziła czytelników do szczęśliwego końca i chwały Bożej”47.

Biskup z Cezarei kończy cały swój komentarz modlitwą prośby i uwielbienia. Objawienie bowiem jest dla rozproszonych chrześcijan pocieszeniem, zachętą do wytrwania i nadzieją. Przy końcu epilogu cytuje za Pawłem, że „Bóg pragnie, aby wszyscy ludzie zostali zbawieni i doszli do poznania prawdy” (1 Tm 2,4) i dodaje jeszcze: „każdy człowiek przyjmuje boskie światło na miarę czystości swych duchowych oczu. Niech temu, który jest miłosierny, Chrystusowi naszemu Bogu, który cierpiał dla nas w ciele i czyni nas godnymi otrzy-

\footnotetext{
43 Tamże VIII, 11, s. 79.

44 MTS 1, 133.

45 Zob. M. Simonetti, Między dosłownościa a alegoria, 314-315.

46 MTS 1,12 do Ap 1,1-2.

47 MTS 1,263 do Ap 22,20-21.
} 
mania łaski czystej i nieskażonej, Jemu niech będzie chwała, cześć i uwielbienie, razem z Ojcem i życiodajnym Duchem, teraz i na wieki. Amen" ${ }^{48}$. Celem napisania Komentarza do Apokalipsy nie jest nic innego, jak pomoc człowiekowi w otrzymaniu łaski Bożej „czystej i nieskażonej”.

\section{Znaczenie komentarza Andrzeja dla krytyki tekstu Apokalipsy}

Andrzej z Cezarei zadał sobie trud, aby dotrzeć do starych rękopisów greckich oraz zebrania wszystkich liczących się interpretacji Apokalipsy, jak np. Papiasza, Justyna, Ireneusza, Hipolita, Metodego, Apolloniusza, Euzebiusza, Epifaniusza, Bazylego i Grzegorza z Nyssy ${ }^{49}$. Charakterystyczny jest fakt, że Andrzej powołuje się na świadectwa Ojców Kościoła jako na wyraźny dowód potwierdzający nadprzyrodzony charakter Księgi Objawienia. Jednak Komentarz do Apokalipsy biskupa z Kapadocji ma jeszcze większe znaczenie dla krytyki tekstu Księgi Objawienia ${ }^{50}$.

Dzieje tekstu greckiego Apokalipsy odzwierciedlają poniekąd losy tej księgi w Kościele greckim. Długo wątpiono w kanoniczność tej księgi, nie używano jej w liturgii, jej tradycja rękopiśmienna w zestawieniu z pozostałymi księgami Nowego Testamentu jest znacznie szczuplejsza. W recenzji zachodniej zupełny jest brak kodeksów z okresu od wieku V do IX ${ }^{51}$. Tym cenniejszą rolę odgrywa tekst Apokalipsy zawarty w komentarzu Andrzeja. Dostrzegł to J. Schmid, monachijski uczony, który najpierw dokonał krytycznego wydania komentarza, a następnie jako owoc dwudziestopięcioletnich żmudnych studiów nad tekstem Księgi Objawienia wydał znakomite i najlepsze na dzień dzisiejszy, cytowane już, trzytomowe dzieło pt. Studien zur Geschichte des griechischen Apokalypse - Textes (MTS). Podstawę w pracy nad krytyką tekstu stanowiła u niego metoda: przez dogłębne badania form późniejszych dochodzić do najstarszych form tekstu. I tak zanim Schmid przeszedł do zbadania starszych form tekstu, uprzednio zajął się rekonstrukcją tekstu, zawartego w komentarzu Andrzeja z Cezarei. Wykazał, że tekst komentarza posiada 75 rękopisów, z których 39 bezpośrednio ma znaczenie dla krytyki tekstu i tworzy całą recenzję o wielu podgrupach. Schmid w swojej pracy nakreślił wzajemny stosunek między naj-

48 MTS 1,267.

49 Por. R. Devreese, Chaines exégétique grecques, Dictionnaire de la Bible, Supplément t. 1, kol. 1230. Zob. E. S. Constantinou, Andrew of Caesarea and the apocalypse..., s. 193194.

50 Zob. L. Stefaniak, Interpretacja 12 rozdziału..., s. 77-83.

51 A. Jankowski, Apokalipsa świętego Jana, Poznań 1959, s. 102. 
starszymi rodzinami greckiego tekstu Apokalipsy a młodszymi, torując tym samym drogę do ustalenia brzmienia oryginału Księgi Objawienia ${ }^{52}$.

Wartość tego komentarza dla krytyki tekstu doceniła również strona niekatolicka. I tak W. Busset stwierdził, że większość rękopisów, w szczególności późniejszych, odznacza się różnorodnością form tekstu oraz pozostaje w ścisłym związku z Komentarzem do Apokalipsy Andrzeja z Cezarei ${ }^{53}$.

\section{Podsumowanie}

Andrzej (VI i VII w.) był arcybiskupem w Cezarei Kapadockiej. W tłumaczeniu Pisma Świętego przyjmuje istnienie potrójnego sensu: wyrazowego, czyli historycznego, moralnego i duchowego, odnoszącego się do przyszłości. Ten ostatni rodzaj sensu Pisma Świętego przeważa - zdaniem Andrzeja - w Apokalipsie Janowej. Mniej więcej w latach 543-614 napisał Komentarz do Apokalipsy, w którym zajął krytyczne stanowisko wobec wykładni Apokalipsy u Ekumeniusza, autora pierwszego w języku greckim komentarza do Księgi Objawienia. Biskup z Kapadocji wypracowuje również swój własny sposób interpretacji Księgi Objawienia. Dzieli komentarz na dwadzieścia cztery księgi ( $\beta i ́ \beta \lambda o \imath)$, nawiązując do dwudzie-

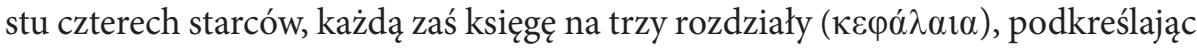
potrójną naturę człowieka (ciało, duszę i ducha) ${ }^{54}$. Interpretuje Apokalipsę raczej syntetycznie i krótko, bez głębszego wnikania w treść teologiczną, chociaż od czasu do czasu, zdarza się, że przy istotnych fragmentach Księgi Objawienia zatrzymuje się dłużej. Sam komentarz Andrzeja jest dla nas wartościowy nie tylko ze względu na zawarte w nim cenne wypowiedzi wielu Ojców Kościoła, ale stanowi ważne świadectwo tekstu greckiego Apokalipsy, którego krytyczne opracowanie do dziś uznawane jest za obowiązującą recenzję tekstu.

\section{Summary}

The article is a brief examination of the most important ancient commentary on the Book of Revelation produced by the Greek East was composed by Andrew, Archbishop of Caesarea, Cappadocia. It not only became the standard patristic commentary in the Eastern Christian tradition and significantly influenced all subsequent Eastern commentaries, but decisively influenced the reception of the Book of Revelation into the canon of the Orthodox Church.

\footnotetext{
52 L. Stefaniak, Interpretacja 12 rozdziału..., s. 80-81.

53 Zob. W. Bousset, Textkritische Studien zum Neuen Testament, Leipzig 1894, s. 5.

54 W.C. Weinrich, Translator's introduction, w: Greek Commentaries on Revelation...,
} s. XXXII. 